Management Dynamics

Vol. 23, No. 1: 93-104, 2020

Shanker Dev Campus

Doi: https://doi.org/10.3126/md.v23i1.35565

\title{
Training and development in Nepalese commercial banks
}

\begin{abstract}
Present study is designed to investigate training and development practices and its relation with performance in Nepalese Commercial Banks. This study is based on descriptive research design and comprehensively developed structured questionnaire. All the commercial bank are considered as the population and 10 bank are selected as random basis for sample banks for the study. The results are based on primary information collected form 200 staffs of 10 different branches of commercial bank of Kathmandu valley. Through the use of descriptive statistics to analyze the data the study found training and development as an integral part of the organizational development in Nepalese commercial banks. In addition, majority of the respondent reported that they acquire technical knowledge and skills, learning and development skills from training program. More specifically the study reveals that Nepalese commercial banks provide adequate importance to the employees training however the training provided are not well planned and designed according to need of the employee. Finally study shows that training and development program are factor responsible for organizational performance and employee satisfaction. Proper and systematic human resource development practices ensures the higher productivity, working efficiency, institutional promise and corporate governance.
\end{abstract}

Keywords: Training and Development, Corporate Governance, Practices, Performance, Commercial Banks

\section{Introduction}

Human resource development is the emerging issue in the fields of economics and modern management. Human resource development practices increases the efficiency and productivity of human resources which tends to decrease the factor cost. Human resource is regarded as the most significant and precious resource in every organizations. A dynamic, motivated and energetic resource can form a successful organization. Employees can contribute and play significant role, contributing their expertise, time and energy to make organization effective, profitable and to be success in overall aspect of the business. By using competent and selfmotivated human resources are able to make things happen to achieve the organization goal. Organizations should constantly think and make sure competent, effectiveness and motivation remain in place on employees at top level. Human resource development is ever lasting process to ensure in developing effectiveness, competencies, motivation and dynamism of employee in a systematic and planning way.

*. Lecturer, Shanker Dev Campus, PhD Scholar, Faculty of Management Tribhuvan University, Kathmandu, Nepal. Email: chalisedr@shankerdevcampus.edu.np 
Training helps to employees modifying their attitude, knowledge, skills throughout the learning experience to achieve the better performance. Similarly, the term development signifies a broader and a long term instructive processes in which managers as well employers obtain theoretical knowledge. Learning is practical foundation and employees learn through their work process and learning environment. Organizational or employees performance exclusively depends how the organization develops and educates its employees.

Human resource development is now a major field in labor economics. Human resource management economics has a major effect on the world through teaching in business schools and ultimately what gets practiced in many organizations. Human resource management covers a wide range of activities. The main area of study has been focused on human resource development practices in the Commercial Banks of Nepal. Human resource development activities include training and development program of staffs of the organization.

\section{Statement of problem}

Human resource development is assumed to be an important aspect for an organization whereas the main issue and trend of human resource development includes training and development. For the growth and development of an organization and achieve its determined objectives, training and development is considered as an effective component because it aims to develop employees skills, knowledge, attitude, capacities and efficiencies. To achieve the desired goals, employees training and development programs plays most effective role in each and any type of organizations. Therefore, this study mainly aimed to examine whether or not Commercial Banks of Nepal adopted effective employee training and development programs enhance organizational performance. As for competitive advantages and overall success of an organization these are the determinant factors.

Human resource development and Employee engagement are interrelated so as in banking sector it can be treated as critical components for work (NRB, 2019). It is very important to improve the organizational performance of banking industry through the employee engagement and Banking sector had to improve the organisational performance through employee engagement and human resource development. Study by Hakuduwal, (2019) found significant impact on employee engagement through training and development, career development and performance management in Nepalese commercial banks. In addition Human resource practice of organizational culture, human resource training and development results positive and significant relationship with organizational citizenship behavior and employee empowerment results the negative on organizational citizenship behavior (Subedi, \& Sthapit, 2020).

Systematically, it can be presented as:

- What types of trainings and development activities are adopting by the Commercial Banks of Nepal?

- What is the interrelationship between employees' training and development with performance? 


\section{Objectives of research}

The general objective of the study is to investigate and observe the employee development and organizational performance. In addition to this, the present study has intended to examine the training, development practices adopted by the Commercial Banks of Nepal. The specific objectives of the study are:

- To analyze the existing the training, development policy and practices conducted by Commercial Banks of Nepal.

- To identify the relationship between employees' development and organizational performance.

\section{Review of literature}

Human resources are not capital, neither income nor material resources constitutes the ultimate basis for the wealth of a nation. Capital and natural resources are passive factors of production, human beings are the active agents who accumulate wealth, exploit material resources, build socio-economic and political organization and carry out national development. Highly skilled human resources is a pre-requisite for overall economic and national development (Harbison, 1993). Hearty and Morley (1994) defined that the ability to recognize and prioritize trainings and development activities and programs as per needs of organization to maximize benefit remain underpinning function for developing training and development of human resource development. Employees training and development is considered as an important component of human resource development. Training is ongoing planned a short term process of utilizing organized measures from which employee acquire knowledge, skills in terms of definite work to be done.

Huselid (1995) has remarked that training and development may be related to firms' performance in many ways. First, training programs increase the firm specificity to employee skills which consecutively increases employee productivity as well as reducing job dissatisfaction that results in employee turnover. Guest (1997) linked human resource management and human resource and performance whereby selection, training, appraisal, rewards, job design and status and security has been used as human resource management practices and commitment, quality and flexibility as human resource management outcomes. Rao (1998) has pointed that human resource development is the development of the employee for the better competencies, dynamism, motivation and effectiveness. Human resource development aims on persistently appraise the proficiency necessities of persons to perform the job and responsibility given to the employees. It also aims at preparing employees for performing their roles and functions which they may be required to perform in the forthcoming days as they go upon the organizational hierarchy or as the organization takes up new tasks through diversification etc. HRD tries to develop the potentiality on employees for future jobs roles in the organization.

Paul and Anantharaman (2003) has proposed that career development programs demonstrate a true organizational interest in the growth of its personnel, which in turn, stimulates commitment and devotion, subsequently, raising personnel productivity and consequently 
economic output. Collins \& Clark (2003) examined that performance-based compensation is the dominant human resource practice that firms are in order to evaluate and reward employees' actions. While performance based compensation can motivate employees are less loyal if they perceive it as a management mechanism to control their behavior (Ahmad \& Schroeder, 2003). Wilkinson and Redman (2006) have suggested that human resource development is concerned with developing human competencies throughout time bound and planned learning practice to improve the creative input of people to achieve organizational goals. Managers of the organization, get the jobs done by working with and through mobilizing people in right time in right place. Human resources need to be developed continuously as a result organization could outperform to achieve organizational goals efficiently and effectively.

Swanson and Elwood (2009) had defined that human resource development is a process of developing and unleashing expertise for the purpose of improving individual, team, work process and organizational system performance. In the organizational context, the development of any individual means the acquisition of innovative capabilities which makes them able to perform their duties easy and effective. Bloom and Reenen (2010) examined that human resource management has changed drastically the last decades, with personnel economics now a major field in labour economics. The mark of the book is to use standard economic tools applied to the special circumstances of managing labor within companies. Human resource management and productivity is an exciting and lively field and has made great studies. It is essence to see its future as being integrated in the research problems of the economics of organization and management which are becoming a major part of modern labor economics. Tabassi, Ramli and Abu (2011) remarked that the training and development effort can further be designed to increase an individual's level of self-awareness, proficiency, skills and motivation to perform his/her job well. Furthermore, training and development are considered as a systematic endeavor by the organization to facilitate the learning of job related behavior on the part of the employees.

CIMA (2015) has pointed that human resource development in any organization is therefore concerned with developing competencies of employees in organizational setting. Human resource development supports to organization to improve capabilities, enhance effectiveness, efficiency in team work, increase job satisfaction, improvement in decisionmaking, management change, conflict and environmental adoption. Wilson (2015) has opined that globalization and needs for the companies to gain sustainable competitive advantage require new and different approaches to recruitment, training, developing and retaining the employees with key skills. Human resource development has the greater role in each and every types of organization regardless whether it is profitable or non-profitable. Managers get the jobs done by working with or through people. It is concerned with developing competencies of people in organizational settings. There are various functions of human resource development such as training, management development, career development and planning, performance appraisal, employees counseling and welfare. Armstrong (2016) remarked that distinctive human resource development practice shape the core competencies 
that determine how firm competes. Human resource development may be seen as a process of building and enhancing the skills, knowledge and attitude of employees. Gnawali (2018) has examined that human resources development practices in NRB in which he found human resource development particularly in training, development performance evaluation system and organizational climate seems to be satisfactory in that organization.

From the above literature review, several international researches have been carried out on human resource development, employees' training and organizational performance. In Nepalese context, it may be perhaps a new and untouched concept and ignored area of inquiry. Only few previous researches have been conducted in the topic of human resource management and need of training, trend of training and development programs. Therefore, present research may be a valuable piece of work for academician, practitioners as well as the banking and financial sector management to understand of importance of human resources development in relation to organizational performance and more importantly to take corrective actions.

\section{Research methodology}

This study has followed descriptive research design to interpret the data which explores how far the human resource and employees' development programs support to enhance the organizational performance as well as employees in fulfill their job responsibilities and satisfaction. The researcher has comprehensively developed the questionnaire taking into consideration various factors of employees' development and performance and result of the previous research related on similar areas or topic. Basic sources of primary information were staffs of 10 Commercial Banks of Nepal at 10 different branches in Kathmandu valley. Beside the primary data, author reviewed the existing literature for in-depth research. For the literature review researcher relied on secondary data to gather information from different previous research books, articles, research journals, internet and media wherever applicable. A large number of employees have been working in the Commercial Banks of Nepal; therefore, the present study could not cover all the employees of the bank because of time and resource constraint. However the research attempts to cover as many to make the result accurate. All the commercial bank are considered as the population of the study and 1o bank were selected as random basis the sample banks for the study. The sample size is only 200 employee working in different eight commercial banks in Kathmandu Valley. Hence Researcher had administered 200 questionnaires on simple random method to collect the information or data. From responses received form 168 questionnaires 150 useable questionnaires were deployed in data analysis. Questionnaires were administered and returned in 10 days. To meet the stated objectives used for design, were used for tabulation and data analysis. Simple descriptive statistical tools have been applied to analysis the data.

\section{Result and discussion}

The present study shows the presentation and analysis of relevant data related to this research in tabular form. It has been analyzed and interpreted the data in such a way that the stated objectives can easily be fulfilled. In the study, 200 questionnaire sheets were administered to collect the data 
and 168 questionnaires were collected from the respondents. However, only 150 responses were in useable form for analysis. The researcher could not incorporate all employees in the research, nevertheless to make study more realistic and accurate information was gathered from different departments by sampling method. The respondents were asked 15 questions out of them seven questions were related to objective- 1 and 8 questions associated to objective-2. Researchers have developed the questionnaires in the form of Yes/No, Agree/Disagree and give opinion to take the view of participants. A general overview of all items and other aspects such as training and development of employee, organizational climate and performance evaluation and employee development planning can be valuable aid to reach in conclusion.

\section{Practices of training and development activities}

Training and development activities are the most effective aspects of human resource development. Human resource development function starts with training and development practices and other skill development activities of human development. For the research purpose, 7 questionnaires were designed and administered to collect information to assess the training effectiveness policies and practices of Commercial Banks of Nepal. Respondents were asked to answer the questions to assess the employees training and development policies and practices adopted by the Commercial Banks of Nepal.

Table-1: Descriptive analysis of training \& development practice

\begin{tabular}{|l|l|c|c|c|c|c|}
\hline S.N. & Statements asked to Respondents & $\begin{array}{c}\text { Agree } \\
(\text { No. })\end{array}$ & $\%$ & $\begin{array}{c}\text { Disagree } \\
(\text { No. })\end{array}$ & $\begin{array}{c}\text { Total } \\
\text { No. }\end{array}$ \\
\hline 1. & $\begin{array}{l}\text { Are employees training provided adequate } \\
\text { importance in the organization? }\end{array}$ & 100 & 66.67 & 50 & 33.33 & 150 \\
\hline 2. & $\begin{array}{l}\text { Training provided here are well planned. Do } \\
\text { you agree or disagree? }\end{array}$ & 79 & 52.67 & 79 & 47.33 & 150 \\
\hline 3. & $\begin{array}{l}\text { Is training and development programs of } \\
\text { sufficient duration? }\end{array}$ & 60 & 40.00 & 90 & 60.00 & 150 \\
\hline 4. & $\begin{array}{l}\text { Training provided heregives good opportunity } \\
\text { of new comers to learn about this organization. } \\
\text { Do you agree? }\end{array}$ & 110 & 73.33 & 40 & 26.67 & 150 \\
\hline 5. & $\begin{array}{l}\text { Norms \& values of the organization are clearly } \\
\text { explained to new employees during training? }\end{array}$ & 105 & 70.00 & 45 & 30.00 & 150 \\
\hline 6. & $\begin{array}{l}\text { Is training periodically evaluated and } \\
\text { improved here? }\end{array}$ & 69 & 46.00 & 81 & 54.00 & 150 \\
\hline 7. & $\begin{array}{l}\text { Do employees acquire technical knowledge } \\
\text { and skill through training? }\end{array}$ & 78 & 52.00 & 72 & 48.00 & 150 \\
\hline
\end{tabular}

Table-1 depicts the number and percent of respondents and their view regarding the employee training and development practice adopted by Commercial Banks of Nepal. The data presented in the table clearly shows that the majority (i.e.66.67\%) of the respondents supported the fact 
of Commercial Banks provide adequate importance to the employees training and only 33.33 percent of the respondents were against that fact. They said that Commercial Banks did not give importance to developing training and development program for the employees.

Regarding the planning of the training, majority of the respondents $(52.67 \%)$ agreed that the training provided in Commercial Banks were not well planned whereas only 47.33 percent of the respondents were positive regarding as well planned. Most of the respondents surveyed $(60 \%)$ reveled their disagreement regarding the statement toward training and development programs are of sufficient duration. Only 40 percent of the respondents were in favor of this statement. It clearly points out the shortcomings in the training and development program provided by the Commercial Banks of Nepal.

Regarding the provision of learning opportunity provided to new comers most the respondents $(73.33 \%)$ agreed that Commercial Banks of Nepal provision of learning opportunity provided to new comers whereas 26.67 percent of respondents were against this view. Employees feel motivated and empowered when they are provided with opportunity to learn and excel. Commercial Banks of Nepal has been found to have the culture of explaining the norms and values to the new comers during training which was supported by 70 percent of the respondents. Only 30 percent of the respondents disagreed on that fact. This indicates that new employees get significant time and opportunity of learning about the organization.

Regarding the query about the periodic evaluation and improvement of training in Commercial Banks of Nepal, 54 percent of the respondents showed disagreement and only 46 percent agreed that Commercial Banks periodically evaluates and improve the training programs. This indicates that training need assessment system in the bank is weak state and it indicates training evaluation is not practiced here.

More than 52 percent respondents reported that they acquire technical knowledge and skills from the trainings, learning and development program, whereas nearly 48 percent of respondents found against the opinion. This indicates that employees require technical knowledge. Regarding training need assessment majority 52 percent of respondents reported that they take part in training need assessment prior to design and carry out the training whereas 48 percent of them reported that they do not provided this opportunity.

It can be summarized that there was agreement among employees in the majority areas of human resource development areas (5 areas). Employees were disagreed only two areas of practices of human resource development activities. Employees of the organization perceived that Commercial Banks are not adequately able to adopt $r$ human resource development. 
Relations of Employee Training, Development and Performance

To investigate the link between employees' development and organizational performance questionnaire consisting 8 topics were delivered to collect the information from the respondents. All together 150 participants were involved in the survey. Most of the respondents emphasized on competent manpower and training, development, education, foreign visit, required nutrition help to enhance the performance. Well skilled, creative, good knowledge and active employees boost up effective communication, implementation of plans and policies, good coordination, motivation and proper monitoring and evaluation with due rewards and punishment.

Table-2: Relations of employees' training, development and performance

\begin{tabular}{|c|c|c|c|c|c|c|}
\hline S.N. & Statements & $\begin{array}{l}\text { Agreed } \\
\text { (No.) }\end{array}$ & $\%$ & $\begin{array}{c}\text { Disagreed } \\
\text { (No.) }\end{array}$ & $\%$ & $\begin{array}{c}\text { Total } \\
\text { Respondents }\end{array}$ \\
\hline 1. & $\begin{array}{l}\text { HRD helps in corporate } \\
\text { governance, coordination and } \\
\text { motivation }\end{array}$ & 103 & 68.67 & 47 & 31.33 & 150 \\
\hline 2. & $\begin{array}{l}\text { Training \& development of } \\
\text { employees helps for change } \\
\text { management }\end{array}$ & 101 & 67.33 & 49 & 32.67 & 150 \\
\hline 3. & $\begin{array}{l}\text { Training, development helps to } \\
\text { improve productivity, market } \\
\text { share, reputation, image, prestige } \\
\text { \& efficient use of resources. }\end{array}$ & 90 & 60.00 & 60 & 40.00 & 150 \\
\hline 4. & $\begin{array}{l}\text { Employee development supports } \\
\text { in corporate governance. }\end{array}$ & 78 & 52.00 & 72 & 48.00 & 150 \\
\hline 5. & $\begin{array}{l}\text { Training \& development for } \\
\text { employees help for change } \\
\text { management\& grievancehandling } \\
\text { effectively \& efficiently. }\end{array}$ & 85 & 56.67 & 65 & 43.33 & 150 \\
\hline 6. & $\begin{array}{l}\text { Training helps to change } \\
\text { challenges into opportunities and } \\
\text { weaknesses into strengths in the } \\
\text { changing environments. }\end{array}$ & 110 & 73.33 & 40 & 26.67 & 150 \\
\hline 7. & $\begin{array}{l}\text { Employees' development helps } \\
\text { to improve productivity, market } \\
\text { share, reputation, image, prestige } \\
\text { and efficiency. }\end{array}$ & 69 & 46.0 & 80 & 54.0 & 149 \\
\hline 8. & $\begin{array}{l}\text { Employees development helps } \\
\text { enhance motivation of personnel. }\end{array}$ & 99 & 66.00 & 51 & 34.00 & 149 \\
\hline
\end{tabular}


Table-2 depicts the agreement and disagreement of respondents and their respective percent in regards to the relationship between employee development and performance. In the response to the statement, human resource development helps in corporate governance, coordination and motivation 68.67 percent of the respondents were agreed and 31.33 percent were disagreed. It indicates that if organization takes an initiative for effective human resource management would help in enhance good governance, capacity, motivation and coordination of organization.

Regarding the training and development, majority of the respondents $(67.33 \%)$ were agreed and only 32.67 percent respondents were expressed disagreement toward the statement. Toward the opinion statement 3, majority of the respondents $(60 \%)$ were agreed and 40 percent expressed their disagreement. Majority of the respondents $(56.67 \%)$ were agreed towards training \& development for employees help for change management \& grievance handling effectively \& efficiently and only 43.33 percent of Majority of respondents (73.33\%) were agreed to this statement and 26.67 percent of respondents were against the statement. Training helps to change challenges into opportunities and weaknesses into strengths in the changing environments.

The majority of respondents $(54 \%)$ were expressed disagreement towards the statement and minorities of respondents (46\%) were agreed to this statement. Regarding the statement of employees development helps enhance motivation of personnel, 66 percent respondents were expressed their agreement and minority of the respondents were expressed their disagreement.

The respondents had expressed that an effective human resource management would help in enhance good governance, capacity, motivation and coordination of organization. Majority of respondents expressed in regard training and development as an important tool for change management. The organization should perceive employee training and development programs create sense of confidence to them. The respondents expressed that for the strengthen the organizational capacity employee should be trained and developed. If the organization provides training and development programs to the employees, it helps to improve productivity, extend market share, reputation in the market or customer. It also enhances the prestige of the organization as well as supports the efficient use of the resources.

The respondents expressed that employees' development program provides an opportunity for quick promotion and self-development for the employees. Training and development program enhance the capacity of the employees on their planning, organizing, directing and controlling task. Similarly, this program helps to handle employee grievance and promotes productivity, confidence, discipline and self-steam adherence. The efficient employees in the 
organization can implement plans, policy and strategy. As the respondents' expression, human resource development can improve decision-making capabilities and cultured thinking of management. Well skilled employees can be adjusted with job related programs. For the purpose of effective operation of financial and accounting system, each and every organization should follow the budgeting and financial management systems. The skilled manpower has mobilized effectively and efficiently to the budgeting and financial management system in the organization.

Sometimes, there may create the problem of goal congruence among the employees due to the lack of controlling. Regarding the quality of work life and commitment they agreed that employees' development leads to commitment, readiness to change, societal well-being, cost effectiveness and the implementation of the policies. From the interpretation of the data it can be concluded that employees' training and development plays a significant role for overall development of any types of organizations. In the context of Commercial Banks of Nepal, employees' development plays the crucial roles for the better performance. The study has found that there is a positive relationship between employees' development and performance of the organization. However, the study finds that training and development programs and activities were insufficient in the organization.

\section{Conclusion and implications}

Human beings have always been complex and having to manage human resources has always been tricky. The emerging development of technology has added more complexity to human resource management such as transparency of social media, persistence of software updates and remoteness of international teams. The main objective of the study was assessing to find out the employees development and organizational performance of Commercial Banks of Nepal. The study was quite successful to meet the determined the objectives of this research. The study was designed to find out the employee development practice, establish the relationship between employee development and organizational performance of the Commercial banks. It is obvious from the analysis of data employees' training and development program has positive relationship with performance. This research can be a valuable piece of research works in human resource development particularly in training, development, performance evaluation system and organizational climate aspects in the Commercial Banks of Nepal. This may be helpful for academicians, banking management and any others who are directly or indirectly involved in business, government and non-government sectors. 


\section{References}

Ahmad, S., \& Schroeder, R. G. (2003). The impact of human resource management practices on operational performance: recognizing country and industry differences. Journal of operations Management, 21(1), 19-43.

Armstrong, M. (2016). Armstrong' Handbook of Human Resource Management Practice.11 $1^{\text {th }}$ Edition, United Kingdom : Kogan Page Limited.

Bloom, N., \& Van Reenen, J. (2011). Human resource management and productivity. In Handbook of labor economics. Elsevier.

Bloom, N. \& Reenen, J.V. (May,2010). Human Resource Management and Productivity. CEP Discussion Paper No.982, Centre for Economic Performance, UK.

Brown, F.W., \& Dodd, N.G. (1998). Utilizing organizational cultural gap analysis to determine human resource management needs. Leadership and Organization Development Journal, 19(7), 374-395.

CIMA (2015). Organization Management and Information System. Delhi: Kaplan Publishing.

Collins, C.J., \& Clark, K.D.(2003). Strategic human practice, top management commitment, team social networks and firm performance: The role of human resource practices inncreating organizational competitive advantages. Academy of Management Journal, 46(6), 740-751.

Gnawali, A. (2018). Human resource development practices: empirical evidence from Nepal Rastra Bank. Kathford Journal of Engineering and Management, 1(1), 57-63.

Guest, D.E. (1997). Human resource management and performance: A review and research agenda. The International Journal of Human Resource Management, 8(3), 263-276.

Hakuduwal, K. (2019). Human resource development and employee engagement in Nepalese commercial banks. Journal of Business and Social Sciences Research, 4(2), 21-34.

Harbison, M.(1993). Predicting business unit performance using employee surveys: Monitoring HRM-related changes. Human Resource Management Journal, 20(1), 44-63.

Heraty, N. \& Morley, M.(1994). Human resource development in Ireland: position, practices and power. Administration, 42(3), 299-320.

Huselid, M.A.(1995). The Impact of human resource management practices on turnover, productivity and corporate financial performance. Academy of Management Journal, $38,635-670$.

Paul, A.K. \& Anantharaman, R.N.(2003). Impact of people management practices on organizational performance: Analysis of a Causal Model. International Journal of Human Resource Management, 14(7), 1246-1266.

Rao,T.V.(1998). The human resource development missionary. New Delhi: Oxford and IBH Publishing Co.Pvt.Ltd. 
Redman, T. \& Wilkinson, A. (2006). Contemporary human resource management- text and cases. Second edition. Prentice Hall, Financial Times.

Subedi, R., \& Sthapit, A. (2020). Association between human resource management practices and organisational citizenship behaviour in nepalese commercial banks. Indian Journal of Commerce and Management Studies, 11(1), 32-45.

Swanson, A.R. \& Elwood, F.H. III (2009). Foundation human resource development. Second Edition. USA: Berrett-Koehler Publication Inc.

Tabassi, A. Ramli, M. \& Abu,B.A.(2011). Training and development of work forces in the construction industry. International Journal of Academic Research, 3(4), 509-515.

Wilson,P.J.(2015).Human resource development. UK: Kogan Page Limited. 